\title{
Management of Persistent Pulmonary Hypertension in Preterm Infants
}

\author{
Byong Sop Lee, MD, PhD
}

Department of Pediatrics, Asan Medical Center, University of Ulsan College of Medicine, Seoul, Korea

\section{ABSTRACT}

Persistent pulmonary hypertension of the newborn (PPHN) is a consequence of the failure of a decrease in the elevated pulmonary vascular resistance after birth. Pulmonary vasodilators, including inhaled nitric oxide (iNO), have been the mainstream of targeted therapy for PPHN, but no drugs have been proven to be effective in preterm infants with PPHN. The fetus remains hemodynamically stable despite lower arterial oxygen tension and pulmonary blood flow as compared to full-term newborns. This adaptation is due to the lower oxygen requirement and high oxygencarrying capacity of fetal circulation. The immature lungs of preterm infants are more vulnerable to reactive oxygen species, and the response of pulmonary vascular dilatation to blood oxygen tension is blunted in preterm infants. Recently, iNO has been reported to be effective in a selected group of preterm infants, such as those with prolonged preterm rupture of membrane-oligohydramnios-pulmonary hypoplasia sequence. PPHN in preterm infants, along with maximum supportive treatment based on fetal physiology and meticulous assessment of cardiovascular function, is in dire need of new treatment guidelines, including optimal dosing strategies for pulmonary vasodilators.

Key Words: Persistent fetal circulation syndrome; Hypertension, pulmonary; Nitric oxide; Infant, premature; Premature rupture of fetal membrane

서론

폐혈관 긴장도 조절은 내피세포와 평활근에 걸쳐 작용하는 (1) 산화질소(nitric oxide, NO)고리일인산구아노신(cyclic guanosine monophosphate) 경로, (2) prostaglandin analog-고리 일인산아데노신(cyclic adenosine monophosphate) 경로, 그리고 (3) 엔도텔린(endothelin) 경 로를 통해 이루어진다. 각 경로상의 표적 물질을 자극 또는 억제하여 폐혈관을 확장시키는 표적 치료제(targeted therapy)는 이 시간에도 활발히 개발되고 있다(Figure 1) ${ }^{1)}$. 다양한 폐동맥고혈 압 중 신생아기 폐동맥고혈압은 크게 (1) 태아기에 높게 유지되던 폐혈관저항이 출생 후에도 감 소하지 않거나 (2) 만성폐질환 때문에 폐혈관이 함께 손상되는 경우로 구분된다. 전자를 신생아 지속성 폐동맥고혈압(persistent pulmonary hypertension of the newborn, PPHN)으로 정의한
Received: 9 September 2020

Revised: 16 October 2020

Accepted: 20 October 2020

Correspondence to: Byong Sop Lee, $\mathrm{MD}, \mathrm{PhD}$

Department of Pediatrics, Asan Medical Center, University of Ulsan College of Medicine, 88 Olympic-ro 43-gil, Songpa-gu, Seoul 05505, Korea Tel: +82-2-3010-3929

Fax: +82-2-3010-6978

E-mail: mdleebs@ amc.seoul.kr

Copyright(c)

By Korean Society of Neonatology.

All right reserved.

This is an Open-Access article distributed under the terms of the Creative Commons At tribution Non-Commercial License (http:// creativecommons.org/licenses/by-nc/4.0), which permits unrestricted non-commercial use, distribution, and reproduction in any medium, provided the original work is pro perly cited. 
다. 폐동맥고혈압이 지속되는 이유는 태아기 또는 주산기의 어떤 요 인이 출생 후의 정상적인 폐혈관 확장을 저해하거나 비정상적 변형 을 유발하는 것으로 요약된다.

만삭아에 비해 미숙아는 PPHN의 유병률과 사망률이 높다 ${ }^{2)}$. 일본 레지스트리 연구에 따르면 재태주령 28주 미만의 초미숙아 1,000명 당 PPHN의 유병률은 약 81명으로 이는 만삭아(1.6명) 및 후기 조산 아(5.4명)에 비하여 매우 높았고, PPHN이 있는 미숙아의 퇴원 전 사 망률(30.4\%)은 PPHN이 없는 경우(9.6\%)에 비하여 높았다 ${ }^{3)}$. 이는 혈역학적 안정성 측면에서 만삭아에 비하여 취약한 미숙아에서 예 상되는 결과이다.

신생아에서 폐혈관저항의 상승은 우심실의 수축 및 이완기 기능 장애와 동맥관과 난원공을 통한 우-좌단락을 유발한다. 폐혈류의 감 소는 좌심실로의 전부하 감소와 함께 폐환기와 산소화의 장애를 가 져오며 이는 결국 좌심실 기능의 감소와 좌심실 구축량의 감소를 일 으킨다. 결국 폐포에서의 산소교환과 전신으로의 산소 공급이 동시 에 부족해지는 상황은 쇼크로 이어질 수밖에 없단). 여러 보존적 치 료와 더불어 빠른 시간 내에 폐혈관저항을 낮추는 표적 치료가 필요 한 이유이다. 그러나 아쉽게도 신생아 PPHN에서 무작위 대조군 연 구가 진행된 약물은 흡입 일산화질소(inhaled nitric oxide, iNO)와 sildenafil (Viagra, Pfizer, New York, NY, USA)밖에 없다. 또한 미 숙아에서 한정된 무작위 대조군 연구가 있는 것은 $\mathrm{iNO}$ 가 유일하다.

\section{급성호흡부전 미숙아에서 흡입 일산화질소의 효과}

90년대부터 발표된 연구를 메타 분석한 최근 Cochrane 분석에 따 르면 $\mathrm{iNO}$ 는 만삭아 또는 준만삭아의 저산소증에서 사망 또는 체외 막산소화술(extracorporeal membrane oxygenation, ECMO) 사용 빈도를 감소시켰다 ${ }^{5}$. 그러나 이런 주요 결과는 사망률 자체보다는 $\mathrm{ECMO}$ 사용을 낮추는 효과 때문이었다. 또한 $\mathrm{iNO}$ 는 선천성 횡격 막 탈장에서 발생한 PPHN에는 효과가 없었다. 재태주령 34주 미 만 급성 호흡부전 미숙아를 대상으로 분석한 다른 Cochrane 분석 에서 $\mathrm{iNO}$ 는 사망이나 사망 또는 기관지폐이형성증이라는 주요 결 과를 감소시키지 못하는 것으로 결론지었닿. 이 분석에 포함된 가 장 큰 무작위 대조 연구는 2005년 Van Meurs 등ㄱㅇㅔ 의해 발표되었 는데 재태주령 34주 미만의 급성 호흡부전 미숙아 420명에서 $\mathrm{iNO}$ 는 사망률을 낮추지 못하였다. 심지어 출생체중 $1,000 \mathrm{~g}$ 이하 환자군 에서는 $\mathrm{iNO}$ 가 사망과 중증 뇌실내출혈 또는 뇌실주위백질연화증의 빈도를 증가시키는 것으로 나타났다. 이런 결과는 미국 식품의약안 전청 등 권위 있는 기관에서 iNO를 만삭아 또는 준만삭아의 PPHN 에만 제한하여 사용하도록 하는 지침에 영향을 미쳤다. 우리나라 역 시 재태주령 34 주 미만 미숙아 또는 선천성 횡격막 탈장의 PPHN에 대한 의료용 iNO (INOmax, Synex, Seoul, Korea) 사용에 대한 보험
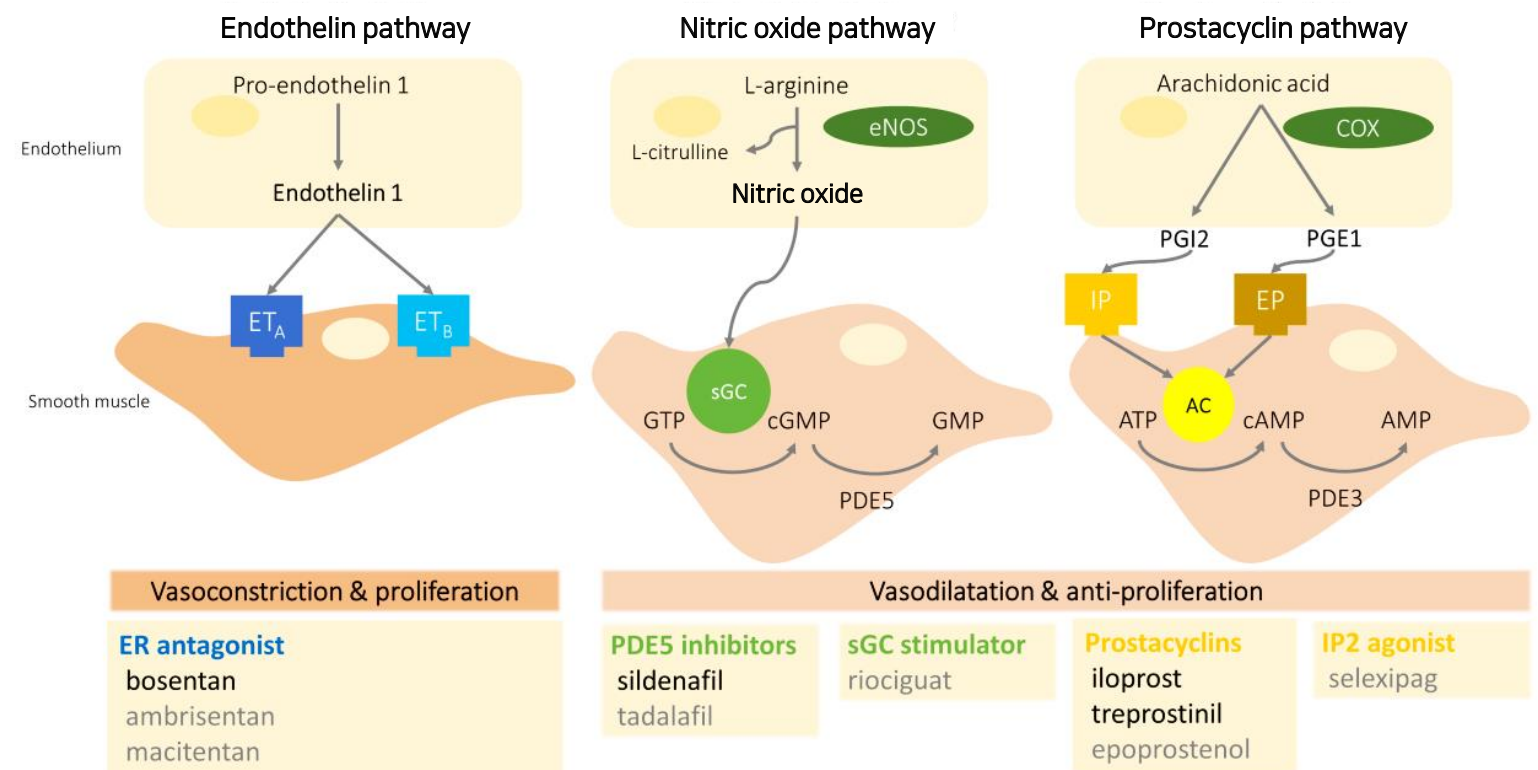

Vasoconstriction \& proliferation
ER antagonist
bosentan
ambrisentan
macitentan

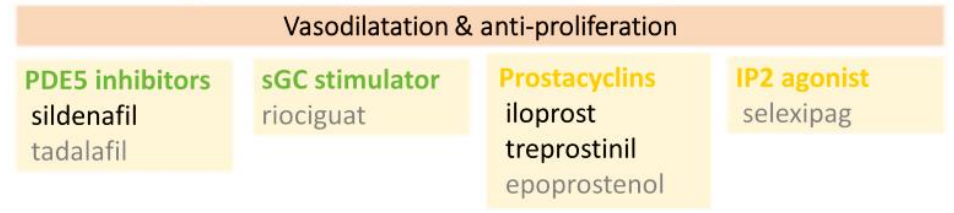

Figure 1. The three major pathways involved in pulmonary vascular regulation and Food and Drug Administrationapproved medications for the treatment of pulmonary hypertension. Abbreviations: ET, endothelin receptor; eNOS, endothelial nitric oxide synthase; GTP, guanosine triphosphate; sGC, soluble guanylyl cyclase; cGMP, cyclic guanosine monophosphate; GMP, guanosine monophosphate; PDE5, phosphodiesterase 5; COX, cyclooxygenase; PGI2, prostacyclin; PGE1, prostaglandin E1; IP, prostaglandin I2 receptor; EP, prostaglandin E1 receptor; ATP, adenosine triphosphate; AC, adenylyl cyclase; cAMP, cyclic adenosine monophosphate; AMP, adenosine monophosphate; PDE3, phosphodiesterase 3; ER, endoplasmic reticulum. 
급여를 인정하지 않고 있다 ${ }^{8}$. 학회는 이와 같은 급여 기준을 벗어나 는 일부 환자군에 대하여도 의료용 iNO 사용이 가능하도록 노력 중 이지만 아쉽게도 기존 기준을 반박할 만한 근거를 모으는 데 어려움 을 겪고 있다.

미숙아 PPHN에서 iNO의 긍정적 치료 결과를 보고한 연구는 많 지 않다. 그나마 규모가 큰 연구는 일본 PPHN 레지스트리 연구이다 9). 생후 7일 이내 PPHN으로 등록된 자료 분석에서 $\mathrm{iNO}$ 는 재태주령 34 주 이상 신생아는 물론, 34 주 미만 미숙아에서도 경증부터 중증에 걸친 모든 아군에서 산소화 개선 효과를 보였다. 특히 치료 전 산소 화 지수(oxygenation index, OI)가 40이 넘는 미숙아의 생존율도 64 $\%$ 에 이르는 것으로 보고하였다. 최근 American Heart Association 과 American Thoracic Society가 제시한 소아 폐동맥고혈압 치료 가 이드라인은 폐실질 병변이 아닌 PPHN에 일차적으로 기인하는 중증 저산소증, 특히 장기간의 조기양막파열(preterm premature rupture of membrane, PPROM)과 양수과소증(PPROM-oligohydramnios)으 로 생기는 폐형성부전(pulmonary hypoplasia)이 의심되는 미숙아 $\mathrm{PPHN}$ 환자들에서 선택적으로 $\mathrm{iNO}$ 사용이 도움을 줄 수 있을 것이 라 언급하고 있다 ${ }^{10)}$. 이런 특성을 가진 미숙아 PPHN 증례 보고와 후 향적 연구를 취합한 최근 보고서를 참조하면 $\mathrm{iNO}$ 는 전체 환자의 약 $94 \%$ 에서 산소화를 개선시키고 생존율을 $85 \%$ 까지 향상시키는 것으 로 보인다 ${ }^{11}$. PPHN이라는 공통적인 병태생리에도 불구하고 왜 일 부 환자군에서만 iNO의 효과가 나타나는지에 대한 연구는 부족하 다. 핀란드의 연구에서는 PPROM에 합병된 호흡곤란이 있는 $\mathrm{iNO}$ 치료 반응군에서 대조군에 비하여 iNO 치료 전 nitrite와 nitrate 등 일산화질소 관련 대사 물질이 유의하게 감소되어 있어 조기양막파 열-양수과소증-폐형성부전 환자군에서 특징적으로 내인성 $\mathrm{NO}$ 생성 의 결함이 있을 가능성을 시사하였다 ${ }^{12)}$. 정리하면 $\mathrm{iNO}$ 는 호흡부전 이 동반된 미숙아 PPHN의 효과가 확인된 것은 아니지만 특징적 병 태생리를 갖는 일부 환자군에서는 단기적이나마 산소화 개선 효과 를 통해 임상 경과에 영향을 미칠 수 있는 것으로 보인다.

\section{태아 순환 생리와 미숙아 PPHN}

태아의 폐혈류량은 전체 심박출량의 $13 \%-25 \%$ 범위에 있으며 폐 혈류량 대 체혈류량의 비율도 20\%- $40 \%$ 정도에 불과하다 ${ }^{13)}$. 출생 후 정상적으로 폐혈류가 증가하지 못한 PPHN 미숙아는 순환적 측면에 서 볼 때 태아의 혈역학적 상태에 더 가깝다고 볼 수 있다. 태아 혈 액의 산소 분압과 폐혈류량은 건강한 신생아에 비해 현저히 낮다. 예를 들어 제대 정맥혈을 제외하고 태아에서 가장 높은 산소포화도 를 보이는 상행 대동맥의 동맥혈 산소 분압과 산소포화도는 각각 25 $\mathrm{mm} \mathrm{Hg}$ 과 $65 \%$ 에 불과하다 ${ }^{14)}$. 그럼에도 불구하고 태아가 안정적인 상태에 있는 이유는 만삭아에 비해 상대적으로 폐순환량이 적고, 폐
의 산소 요구량이 낮고, 태아 혈액의 산소 운반 능력이 우수하기 때 문이다. 신생아 PPHN 치료의 단기적 목표는 적절한 환기와 관류를 확보함으로써 전신 순환으로의 안정적인 산소 공급량을 확보하는 것이다. 그렇지만 태아 순환과 유사한 상태에 있는 PPHN 미숙아의 순환을 급격히 정상 만삭아 수준으로 전환하는 것에는 위험이 따를 수밖에 없다. 일례로 혈중 산소 분압에 대한 미숙아의 폐혈관 확장 반응은 만삭아와 다르기 때문이다.

태아의 동맥혈 산소 분압은 산모에 비하여 좁은 범위에서 안정적 으로 유지된다. 임신한 양에게 $100 \%$ 산소를 공급하여 동맥혈 산소 분압을 $400 \mathrm{~mm} \mathrm{Hg}$ 까지 상승시키더라도 태아 제대정맥과 상행대동 맥의 산소 분압 증가 폭은 각각 $10 \mathrm{~mm} \mathrm{Hg}$ 과 $5 \mathrm{~mm} \mathrm{Hg}$ 정도로 최대 $50 \mathrm{~mm} \mathrm{Hg}$ 과 $35 \mathrm{~mm} \mathrm{Hg}$ 까지 밖에 상승하지 않는다. 태반이 일차적 으로 고농도 산소에 대한 완충작용을 하고 동맥혈 산소 분압이 증가 되면 폐혈류가 증가하면서 체혈류가 상대적으로 감소하기 때문이 다 ${ }^{14)}$. 또한 혈중 산소 분압에 대한 태아의 폐혈류 변동은 재태주령 에 따라 다르다. 산모에게 $\mathrm{FiO}_{2} 60 \%$ 농도의 유량을 공급하면서 도플 러 검사로 태아의 폐혈류 지표를 확인했을 때 재태주령 20-26주의 환자군은 폐혈류의 변화가 거의 없지만 31-36주의 태아군은 폐동맥 저항 감소와 폐혈류 증가 반응이 나타났다 ${ }^{15)}$. 이는 재태주령이 어린 미숙아일수록 혈중 산소 분압 증가에 대한 폐혈관저항 감소 반응이 뚜렷하지 않은 것을 시사한다.

Superoxide나 hydrogen peroxide 같은 활성산소(reactive oxygen species)는 폐혈관 확장 경로의 곳곳에 관여하여 폐혈관 수축과 비 정상적 혈관 리모델링을 유발한다. 태아는 superoxide dismutase, catalase와 glutathione peroxidase 등 항산화효소의 활성도가 신생 아에 비해 현저히 낮고 이는 재태주령이 어릴수록 낮다 ${ }^{16}$. 즉, 미숙 아 폐는 만삭아 폐에 비해 고농도 산소에 대한 보호 장치가 약하고 따라서 더 많은 활성산소의 효과가 나타난다. 활성산소는 자체로 폐 혈관 수축과 손상을 유발할 뿐 아니라 폐동맥고혈압 치료 목적으로 투여된 iNO와 결합하여 peroxynitrite로 불활성화시키면서 iNO의 치료 효과를 감소시킨다. 또한 혈관의 리모델링을 유발한다.

\section{미숙아 PPHN에서의 산소와 흡입 일산화질소}

전통적으로 산소 치료는 신생아 PPHN 치료의 중심에 위치해 왔 으며 동맥혈 산소 분압은 생리적 범위 또는 그 이상 유지하는 것을 목표로 삼아왔다. 이에 근거한 교과서적인 신생아 PPHN의 치료 지 침은 60-100 mm Hg 정도의 $\mathrm{PaO}_{2}$ 를 목표로 하고 저산소혈증 또는 고산소혈증을 피하는 것이다 ${ }^{17)}$. 앞서 언급한 American Heart Association/American Thoracic Society 가이드라인에서도 ECMO 치료 가 필요하거나 OI 25 가 초과하는 저산소증에서 $\mathrm{iNO}$ 를 치료할 것을 권고하고 있다 ${ }^{18)}$. 즉, 현 지침은 산소 치료에 대한 폐동맥 확장 반 
응이 없을 경우 $\mathrm{iNO}$ 를 구제 치료(rescue therapy)의 개념으로 시작 하는 것이다. 그렇지만 미숙아 PPHN에서도 이런 원칙을 동일하게 적용하는 것이 과연 옳은지 의문이다. 태아 동맥관 폐쇄로 유발된 $\mathrm{PPHN}$ 동물모델은 동맥혈 산소 분압에 대한 폐혈관 확장 반응이 정 상 신생아와 다르다. 정상 태아 동물 모델은 $\mathrm{PaO}_{2}$ 를 상승시키면 50 $\mathrm{mm} \mathrm{Hg}$ 을 넘어서면서 급격한 폐혈관저항의 감소가 관찰된다. 반면 $\mathrm{PPHN}$ 동물 모델에서는 $\mathrm{PaO}_{2} 14 \mathrm{~mm} \mathrm{Hg}$ 을 넘어가면서 급격히 폐혈 관저항이 감소하다가 이후 $60 \mathrm{~mm} \mathrm{Hg}$ 까지 상승시키는 경우 폐혈관 저항의 감소가 완만해지고, $60 \mathrm{~mm} \mathrm{Hg}$ 이상의 범위에서는 폐혈관저 항의 변화가 거의 없다 ${ }^{19)}$. 만삭 신생아 $\mathrm{PPHN}^{\circ}$ 에서도 $\mathrm{FiO}_{2} 1.0$ 까지 도 달한 후 $\mathrm{iNO}$ 를 시작한 경우가 $\mathrm{PPHN}$ 초기에 $\mathrm{iNO}$ 를 투여한 환자들에 비해 산소화 개선 효과가 낮고 치료 실패율이 높아지는 결과가 보고 된바 있다 ${ }^{20)}$.

급성호흡부전이 있는 미숙아가 아닌 심초음파상 확인된 중증 $\mathrm{PPHN}$ 미숙아에 한정된 iNO 치료 효과에 대한 전향적 연구는 없으 며 후향적 연구도 많지 않다. Kumar 등른 재태주령이 어릴수록 $\mathrm{iNO}$ 에 대한 치료 효과가 낮아 29주 미만 미숙아는 $16 \%$ 에서만 $\mathrm{iNO}$ 에 대한 치료 반응을 보인다고 하였다. Dani 등 ${ }^{21}$ 은 재태주령 30 주 미만, 출생체중 $1,250 \mathrm{~g}$ 미만의 중증 호흡곤란증후군 환자군을 대상 으로 한 연구에서 PPHN이 있는 환자에서 $60 \%$ 의 iNO 치료 반응과 $43 \%$ 의 사망률을 보고하였다. 이 연구는 iNO의 반응에 따른 결과 분 석은 포함되지 않았다. Baczynski 등22)은 평균 재태주령 28주 미숙 아 PPHN 환자 중 생후 3 일 이내에 $\mathrm{iNO}$ 를 투여한 경우 46\%에서 치 료 반응을 보였으며 치료 반응군은 대조군에 비하여 유의하게 사 망률과 향후 장애의 유병률이 낮다고 하였다. 우리나라에서도 중 증 미숙아 PPHN에서의 $\mathrm{iNO}$ 효과에 대한 단일 기관 연구가 최근 발 표되었다 ${ }^{23)}$. 평균 재태주령 26.1주, 기저 OI 63.8의 중증 PPHN군에 서 $\mathrm{iNO}$ 치료는 환자의 $73 \%$ 가 치료 시작 후 1 시간 째부터 $\mathrm{OI}$ 와 $\mathrm{FiO}_{2}$ 의 빠른 호전을 보였다. 그러나 $\mathrm{iNO}$ 반응군과 무반응군의 생후 1 년 사망률은 각각 $44 \%$ 와 $33 \%$ 로 차이가 없었다. 지금까지의 한정된 연 구들을 정리하면 PPHN에 이환된 재태주령 28주 이하의 초미숙아 에서도 $\mathrm{iNO}$ 에 대한 반응은 어느 정도 양호한 것으로 보인다. 그럼 에도 불구하고 $\mathrm{iNO}$ 치료가 미숙아 PPHN의 주요 합병증과 사망을 감소시키는 증거는 부족하다. 이런 실망스러운 결과는 기존 진료지 침, 즉 $\mathrm{iNO}$ 투여 전후로 환아를 지속적인 활성산소 독성에 노출시키 게 되는 고농도 산소 투여 방침이 $\mathrm{iNO}$ 의 긍정적인 효과에도 불구하 고 만성폐질환의 발생과 사망률 증가에 악영향을 미칠 가능성을 배 제할 수 없다.

\section{조기양막파수-양수감소증-폐형성부전 미숙아 $\mathrm{PPHN}$ 의 치료}

비록 $\mathrm{iNO}$ 가 모든 미숙아 PPHN에 효과적이지는 않다고 하더라도 선택적으로 폐혈관 확장제의 효과를 기대할 수 있는 것으로 알려진 조기양막파수-양수감소증-폐형성부전 미숙아 PPHN에 대한 치료 가이드라인에 대한 정리가 필요하다. 분만 전 양수주입술(amnioinfusion) 등 가능한 산전 치료가 시도된 바 있으나 무작위 대조 연 구에서의 결과는 회의적이다 ${ }^{24,25)}$. 분만 후 적어도 30-60초가 지난 후 제대를 묶는 지연성 제대 결찰(delayed cord clamping)은 미숙 아에서 괴사성 장염과 중증 뇌실내출혈을 감소시키는 것으로 알려 져 최근 미국 산부인과학회에서 활발한 미숙아에 대한 시행을 권고 하고 있다 ${ }^{26)}$. 이는 태아 혈액의 추가적 수혈로 출생 후 적혈구 수혈 의 빈도를 감소시키고 태아 적혈구의 특성을 장시간 유지하는 측면 에서 생리적 이점을 기대할 수 있다. 태아 적혈구의 hemoglobin $\mathrm{F}$ 는 $\mathrm{PaO}_{2} 25-35 \mathrm{~mm} \mathrm{Hg}$ 의 낮은 동맥혈 산소 분압 범위에서 성인 혈 액 hemoglobin $\mathrm{A}$ 의 $\mathrm{PaO}_{2}$ 범위 40-97 mm Hg에서와 동일한 단위 혈 액량 당 산소 운반 능력을 보인다 ${ }^{27)}$. 일반적으로 PPHN 신생아는 산 소 공급 확보를 위한 충분한 적혈구용적률 유지가 권장되지만, 과도 한 “성인 적혈구”의 수혈은 자칫 산소 공급 측면에서 장점을 가진 태 아 또는 미숙아 적혈구의 이점을 희석시킬 가능성이 있다.

폐형성부전 환자는 기흥 등 공기누출증후군의 위험이 상대적으 로 높으므로 낮은 최고 흡기압과 일회 환기량의 고식적 인공환기 요법 또는 초기의 고빈도 환기 시도가 필요하다. 교과서적 지침은 없으나 $\mathrm{PaCO}_{2}$ 를 $60 \mathrm{~mm} \mathrm{Hg}$ 미만으로 유지하기 위해 최고 흡기압 25- $28 \mathrm{cmH}_{2} \mathrm{O}$ 또는 일회 환기량 $6 \mathrm{~mL} / \mathrm{kg}$ 을 초과하는 고식적 인공환 기 설정이 필요한 경우 고빈도환기 요법으로의 전환이 추천된다 ${ }^{28}$. 많은 경우 승압제 치료가 필요하다. 일반적으로는 폐혈관저항을 극 복할 수 있는 평균 동맥압 수준을 유지할 것이 권장되지만 전신혈압 의 증가가 반드시 폐혈관의 관류 증가로 연결되는 것은 아니다. 따 라서 심초음파 상의 다양한 폐혈관저항 지표와 함께 좌심실 기능과 동맥관과 난원공을 통한 단락 방향 등 여러 요인을 함께 고려해야 한다. 예를 들어, 현저한 좌심실 기능 부전이 있으면서 동맥관을 통 한 우-좌 단락과 난원공을 통한 좌-우 단락이 동시에 관찰된다면 이 는 폐정맥 압력 상승과 우심 의존성 체순환 상황을 시사한다. 이 경 우 $\mathrm{iNO}$ 와 같은 선택적 폐혈관 확장제 사용은 오히려 폐부종 악화로 체순환에 악영향을 미칠 수 있다 ${ }^{29)}$. 이 상황에서는 심근 수축력을 증 가시키면서 폐혈관저항을 낮추는 기전의 milrinone을 고려할 수 있 다. 이처럼 미숙아 PPHN에서 catecholamine은 약재별 기전과 효과 에 따라 선택할 수밖에 없다. 대부분 만삭아 또는 영아에 대한 연구 결과지만 dobutamine, epinephrine과 norepinephrine은 폐혈관 대 체혈관 압력비를 감소시키는 반면 dopamine은 이를 증가시킨다. 이 중에서 norepinephrine은 추가로 내인성 $\mathrm{NO}$ 분비를 촉진하면서 
산소 소모량을 감소시키는 효과가 있으므로 PPHN 관련 저혈압의 초기, 특히 자궁내 감염이나 조기 패혈증에 합병된 PPHN의 경우 초 기 승압제로 선택할 것을 고려할 수 있다 ${ }^{30)}$.

빠른 회복을 위하여 여러 심폐기능에 대한 보존적 치료와 함께 표적 폐혈관 확장제의 투여가 필요하다. 미숙아 PPHN에 대한 의 료용 $\mathrm{iNO}$ 사용에 제한이 있는 상황에서 다른 폐혈관 확장제에 대 한 선택의 폭은 제한적일 수밖에 없다. Sildenafil은 만삭아 또는 준 만삭아를 대상으로 한 Cochrane 분석에서 위약군에 비하여 산소 화를 개선시켰다. 다만 $\mathrm{iNO}$ 등 적극적 치료 대조군과 비교하였을 때 사망률 감소 효과는 확인할 수 없었다 ${ }^{31}$. 무작위 대조 연구는 없지만 milrinone과 prostaglandin analogue도 대안 중 하나이다. 생후 24 시간 이내에 발생한 미숙아 PPHN에서 $0.33 \mu \mathrm{g} / \mathrm{kg} / \mathrm{min}$ 에서 $0.5 \mu \mathrm{g} /$ $\mathrm{kg} / \mathrm{min}$ 범위 용량의 milrinone 지속적 정주가 일시적 혈압 감소의 부작용에도 불구하고 산소화를 호전시키고 $\mathrm{iNO}$ 용량을 감소시켰다 는 보고가 있다 ${ }^{32)}$. Prostacyclin (PGI2) 제제 중 iloprost (Ventavis, Bayer, Leverkusen, Germany)는 흡입용 제재로 사용할 수 있어 전 신 투여 보다 환기/관류 불일치 개선 측면에서 더 효과적일 가능성 이 있다. 만삭아 대상 연구에서 iloprost는 sildenafil에 비해 산소화 개선과 인공환기 기간 단축 등의 측면에서 우수한 효과를 보였다 33). 그러나 nebulizer 투여 시 용량이 부정확하고, 치료 반감기가 짧 아 여러 번 흡입해야 하며, 알칼리 혼합제에 의한 잠재적 기도 손 상 가능성이 있는 등 여러 치료상의 제약이 있다. 또 하나의 PGI2 제재인 treprostinil (Remodulin, United Therapeutics Corporation, Durham, NC, USA)도 신생아 PPHN에서의 효과가 기대되는 약물이 다 ${ }^{33)}$. 보통은 피하 투여가 권장되나 정맥주사도 가능하므로 피하 조 직이 얇은 미숙아에서도 사용이 가능하다. 다만 전신 투여 시 저혈 압의 위험이 높아 효과 용량 범위까지 약물을 천천히 증량하는 것이 원칙이므로 빠른 효과를 기대하기 어렵다. 최근 조기 패혈증에 합병 된 미숙아 PPHN에서 treprostinil의 지속적 정주가 효과적이었다는 증례 보고가 있다 ${ }^{34}$.

\section{결론}

다양한 폐동맥고혈압 치료제가 개발되었지만 아직까지 미숙아 PPHN에서 효과가 입증된 약물은 없다. 그렇지만 조기양막파수-양 수감소증-폐형성부전의 전형적 경과를 보이는 미숙아 등 $\mathrm{iNO}$ 를 비 롯한 선택적 폐혈관 확장제의 새로운 적응증을 발굴하고 이들 환자 군에서 약물의 효능을 확인하려는 노력은 계속되어야 한다. 생리적 으로 소아가 성인과 다르듯, 미숙아 PPHN의 치료 방침도 만삭아와 차별되어야 한다는 개념의 새로운 접근 방법이 필요하겠다.

\section{ARTICLE INFORMATION}

\section{Ethical statement}

None

\section{Conflicts of interest}

No potential conflict of interest relevant to this article was reported.

\section{Author contributions}

Conception or design: B.S.L.

Acquisition, analysis, or interpretation of data: B.S.L.

Drafting the work or revising: B.S.L.

Final approval of the manuscript: B.S.L.

\section{ORCID}

Byong Sop Lee https://orcid.org/0000-0002-1347-4200

\section{Acknowledgments}

None

\section{REFERENCES}

1. Martinho S, Adao R, Leite-Moreira AF, Bras-Silva C. Persistent pulmonary hypertension of the newborn: pathophysiological mechanisms and novel therapeutic approaches. Front Pediatr 2020;8:342.

2. Kumar VH, Hutchison AA, Lakshminrusimha S, Morin FC 3rd Wynn RJ, Ryan RM. Characteristics of pulmonary hypertension in preterm neonates. J Perinatol 2007;27:214-9.

3. Nakanishi H, Suenaga H, Uchiyama A, Kusuda S; Neonatal Research Network, Japan. Persistent pulmonary hypertension of the newborn in extremely preterm infants: a Japanese cohort study. Arch Dis Child Fetal Neonatal Ed 2018;103:F554-61.

4. Jain A, McNamara PJ. Persistent pulmonary hypertension of the newborn: advances in diagnosis and treatment. Semin Fetal Neonatal Med 2015;20:262-71.

5. Barrington KJ, Finer N, Pennaforte T, Altit G. Nitric oxide for respiratory failure in infants born at or near term. Cochrane Database Syst Rev 2017;1:CD000399.

6. Barrington KJ, Finer N, Pennaforte T. Inhaled nitric oxide for respiratory failure in preterm infants. Cochrane Database Syst Rev 2017;1:CD000509.

7. Van Meurs KP, Wright LL, Ehrenkranz RA, Lemons JA, Ball MB, Poole WK, et al. Inhaled nitric oxide for premature infants with severe respiratory failure. N Engl J Med 2005;353:13-22. 
8. Ha J, Lee EH, Park HK, Choi BM. Clinical status of inhaled nitric oxide treatment in infants with persistent pulmonary hypertension of the newborn in Korea: post-marketing surveillance results. Neonatal Med 2020;27:57-64.

9. Suzuki S, Togari H, Potenziano JL, Schreiber MD. Efficacy of inhaled nitric oxide in neonates with hypoxic respiratory failure and pulmonary hypertension: the Japanese experience. J Perinat Med 2018;46:657-63.

10. Abman SH, Hansmann G, Archer SL, Ivy DD, Adatia I, Chung WK, et al. Pediatric pulmonary hypertension: guidelines from the American Heart Association and American Thoracic Society. Circulation 2015;132:2037-99.

11. de Waal K, Kluckow M. Prolonged rupture of membranes and pulmonary hypoplasia in very preterm infants: pathophysiology and guided treatment. J Pediatr 2015;166:1113-20.

12. Aikio O, Metsola J, Vuolteenaho R, Perhomaa M, Hallman M. Transient defect in nitric oxide generation after rupture of fetal membranes and responsiveness to inhaled nitric oxide in very preterm infants with hypoxic respiratory failure. J Pediatr 2012; 161:397-403.

13. Rasanen J, Wood DC, Weiner S, Ludomirski A, Huhta JC. Role of the pulmonary circulation in the distribution of human fetal cardiac output during the second half of pregnancy. Circulation 1996;94:1068-73.

14. Lakshminrusimha S, Saugstad OD. The fetal circulation, pathophysiology of hypoxemic respiratory failure and pulmonary hypertension in neonates, and the role of oxygen therapy. J Perinatol 2016;36 Suppl 2:S3-11.

15. Rasanen J, Wood DC, Debbs RH, Cohen J, Weiner S, Huhta JC. Reactivity of the human fetal pulmonary circulation to maternal hyperoxygenation increases during the second half of pregnancy: a randomized study. Circulation 1998;97:257-62.

16. Berkelhamer SK, Farrow KN. Developmental regulation of antioxidant enzymes and their impact on neonatal lung disease. Antioxid Redox Signal 2014;21:1837-48.

17. Steinhorn RH. Pulmonary vascular development. In: Martin RJ, Fanaroff AA, Walsh MC, editors. Fanaroff and Martin's Neonatal-Perinatal Medicine. 11th ed. Philadelphia: Elsevier, 2020: 1306-19.

18. Porta NF, Steinhorn RH. Pulmonary vasodilator therapy in the NICU: inhaled nitric oxide, sildenafil, and other pulmonary vasodilating agents. Clin Perinatol 2012;39:149-64.

19. Lakshminrusimha S, Swartz DD, Gugino SF, Ma CX, Wynn KA, Ryan RM, et al. Oxygen concentration and pulmonary hemodynamics in newborn lambs with pulmonary hypertension. Pediatr Res 2009;66:539-44.

20. GonzalezA, Fabres J, D'Apremont I, Urcelay G, Avaca M, Gandolfi C, et al. Randomized controlled trial of early compared with delayed use of inhaled nitric oxide in newborns with a moderate respiratory failure and pulmonary hypertension. J Perinatol 2010;30:420-4.

21. Dani C, Corsini I, Cangemi J, Vangi V, Pratesi S. Nitric oxide for the treatment of preterm infants with severe RDS and pulmonary hypertension. Pediatr Pulmonol 2017;52:1461-8.

22. Baczynski M, Ginty S, Weisz DE, McNamara PJ, Kelly E, Shah P, et al. Short-term and long-term outcomes of preterm neonates with acute severe pulmonary hypertension following rescue treatment with inhaled nitric oxide. Arch Dis Child Fetal Neonatal Ed 2017;102:F508-14.

23. Cho JY, Lee BS, Oh MY, Cha T, Jeong J, Jung E, et al. Response to inhaled nitric xxide and clinical outcome in very low birth weight infants with early pulmonary hypertension. Neonatal Med 2020; 27:133-40.

24. van Kempen LEM, van Teeffelen AS, de Ruigh AA, Oepkes D, Haak MC, van Leeuwen E, et al. Amnioinfusion compared with no intervention in women with second-trimester rupture of membranes: a randomized controlled trial. Obstet Gynecol 2019;133:129-36.

25. Roberts D, Vause S, Martin W, Green P, Walkinshaw S, Bricker $\mathrm{L}$, et al. Amnioinfusion in very early preterm prelabor rupture of membranes (AMIPROM): pregnancy, neonatal and maternal outcomes in a randomized controlled pilot study. Ultrasound Obstet Gynecol 2014;43:490-9.

26. Committee Opinion No. 684 Summary: delayed umbilical cord clamping after birth. Obstet Gynecol 2017;129:232-3.

27. Vali P, Lakshminrusimha S. The fetus can teach us: oxygen and the pulmonary vasculature. Children (Basel) 2017;4:67.

28. Lakshminrusimha S, Keszler M. Persistent pulmonary hypertension of the newborn. Neoreviews 2015;16:e680-92.

29. Nair J, Lakshminrusimha S. Update on PPHN: mechanisms and treatment. Semin Perinatol 2014;38:78-91.

30. Qasim A, Jain SK. Milrinone use in persistent pulmonary hypertension of the newborn. Neoreviews 2020;21:e165-78.

31. Kelly LE, Ohlsson A, Shah PS. Sildenafil for pulmonary hypertension in neonates. Cochrane Database Syst Rev 2017;8:CD005 494.

32. James AT, Bee C, Corcoran JD, McNamara PJ, Franklin O, ElKhuffash AF. Treatment of premature infants with pulmonary hypertension and right ventricular dysfunction with milrinone: a case series. J Perinatol 2015;35:268-73.

33. Shivanna B, Gowda S, Welty SE, Barrington KJ, Pammi M. Prostanoids and their analogues for the treatment of pulmonary hypertension in neonates. Cochrane Database Syst Rev 2019;10: CD012963.

34. Park BY, Chung SH. Treprostinil for persistent pulmonary hypertension of the newborn, with early onset sepsis in preterm infant: 2 case reports. Medicine (Baltimore) 2017;96:e7303. 